11. Patil, R. T., Sokhansanj, S., Arinze, E. A., \& Schoenau, G. (1992). Thin layer drying of components of fresh alfalfa. Canadian Agricultural Engineering, 34, 343-343.

12. $W u, H .(2004)$. Alfalfa drying properties and technologies-in review. Nature and Science, 2(4), 65-67

13. Mujumdar, A. S. (Ed.). (2014). Handbook of industrial drying. Crc Press

14. Adapa, P. K., Schoenau, G. J., Tabil, L. G., Arinze, E. A., Singh, A. K., \& Dalai, A. K. (2007). Customized and value-added high quality Alfalfa products: A new concept. Agricultural Engineering International: CIGR Journal

15. Kuchynskas, Z., Osobov, V., \& Freher, Yu.. (1988). The equipment for drying, granulation and briquetting feed. Moskow, Ahropromyzdat, ${ }^{208 .}$

16. Yehorov, B., Burdo, O., Goncharenko, V., \&, Khorenzhyy, N. (2005) Extrusion in the processing of high humidity mixed fodders. Storage and processing of grain, 9, $33-37$.

17. Muller, C. J. C., Cruywagen, C. W., Du Toit, F. J., \& Botha, J. A. (2008). The drying rate and chemical composition of field and artificially dried lucerne hay. South African Journal of Animal Science, 38(4), 350-354

18. Burdo, O. (2008) Energy monitoring of food manufactures. Odessa, Polyhraf, 244.

19. Mujumdar, A. S. (2014). Superheated Steam Drying. Handbook of industrial drying, 421

20. Khorenzhyy, N. (2015). Assessment of productive action animal feed products with the inclusion of moist forage grasses in feeding cattle. Researsh works ONAFT, 1 (46), 70 - 76.

21. Yehorov, B., Kochetova, A., Makarov, O., Brazhenko, V., \& Pulatov, V. (2011) Guidance for course and diploma projects for students of professional training areas 7.05170101, 8.05170101 full-time and distance learning. Odessa, ONAFT.

22. Burdo, O. (2003) Methodical specified for the Study course "Fundamentals of power machinery Management". Odessa, ONAFT, 40.

23. Prakhovnyk, A., Solovei, A., \& Prokopenko V. Energy management, Kyiv: IEENTUU «KPY», 472.

24. Rules of organization and management of the process of production of animal feed products (1998). K .: The Ministry of agriculture of Ukraine, Kyiv Institute of bread, 220.

25. Yehorov B., Goncharenko, V., \&, Khorenzhyy, N. (2004) Extruded fodder based on alfalfa cutting. Grain products and mixed fodders, 3, $30-34$.

26. Yehorov, B., Goncharenko, V., \&, Khorenzhyy, N. (2004) Technological fundamentals of batch production technology of fodder for cattle. Zb. dop. mizhnar. konf. "Ukraine. Compouned feeds - 2004”, Kyiv, 70- 72.

Надійшла 13.09.2016. До друку 22.09.2016

\title{
LABOUR PROTECTION AND INDUSTRIAL SAFETY IN UKRAINE: PROBLEMS OF TRANSITION PERIOD AND PERSPECTIVE WAYS OF DEVELOPMENT
}

Abstract.

Based on comparative analysis of the industrial accident causes in Ukraine and EU countries this article establishes that the main accident reasons are organizational ones (50 to 70\% of the total number of cases), however such indicators as the registered in Ukraine fatal cases frequency coefficient (per 1 thousand of employees) and the fatal accidents-total accidents number ratio are greater than the similar indicators in Europe by about 2- and 100-fold, respectively.

It is noted that the issues of improving the work safety in Ukraine towards the association with the European Union should be considered in the context of two main planes, which are associated with changes in the legislative and educational systems.

Within this article, the authors analyse the main inter-sectoral and sectoral regulatory legal acts on labour protection, in particular in the field of providing for fire, explosion and electrical safety, and relevant documents relating to the creation and maintenance of a comfortable environment at work.

Based on the conducted analysis, the problems of adapting the national legislation in the field of labour protection and industrial safety to the legal framework of EU, the problems concerning the unsystematic character and selective approach to the implementation of appropriate changes, and potential hazards that can occur at all stages of the life cycle of technical systems in the event of their introduction are determined.

The main differences in the systematic approach to the professional training of students in higher educational institutions (HEI) of Ukraine and EU countries (Poland, for example) in the field of labour protection and industrial safety are singled out. It is noted that in the Republic of Poland numbering the population correlative with Ukraine the quantity of special educational institutions preparing specialists in the field of labour protection in relation to the total number of higher educational establishment is 1.9 fold greater than the corresponding figure in Ukraine, and the number of subjects with regard to the issues of the labour protection and industrial safety, which are taught to students in fulfilling the work programmes at nonspecialised Polish higher educational establishments is greater than that in Ukrainian several fold.

The statistical data regarding the dynamics of the accident number increase in Ukraine and their causes within a period of 
2015 and 2016 are presented and analysed in the context of recent negative changes including the reduction of class hours for students learning the disciplines of "Sectoral Labour Protection", "Basics of Labour Protection", "Foundations of Life Activity Safety" and "Civil protection", merging such subjects, and cancellation of the graduation project relevant sections in most HEI of Ukraine

On the grounds of the research, priority directions for developing the labour protection and industrial safety in Ukraine on the stage of European integration are proposed.

Key words: labour protection, industrial safety, regulatory framework, Association with EU, legislation, education, danger and technical system.

Sustainable path of social evolution involves the continuous development and improvement of economic, social and other systems of a particular state. The foundation of this process is the regulatory framework, in particular for the labour protection provides a basis for their safe operation and also forms the educational and cultural level of the society, which produces and sells certain products and services.

The regulatory framework in this case must ensure not only the efficiency of the above mentioned systems, but of all the security of workers in the production environment. However, the security of workers also depends, and even more so, on every person understanding of the importance of the private and public security and work culture. This understanding is first and foremost formed in the process of obtaining special education and directly depends on its quality.

To put it in other words, it is clear that certain systemic changes in the state are closely associated with those in the regulatory framework and with the appropriate changes in the education system. Experience of developed countries in the development of economic systems proved that an increased level of work culture increases that of production efficiency and safety at the same time. However, in respect of our state, the issue of ensuring the necessary level and quality of labour protection and industrial safety, both in terms of production and especially at the stage of training young professionals in educational institutions is somewhat problematic.

The need to adapt the existing legislative framework, in particular that in the field of labour protection and industrial security, to European standards was declared in the framework of the Association Agreement signed between Ukraine and EU. However, the same Agreement provides no comprehensive consideration of this issue in the context of the relevant educational reform. This approach hides certain risks, which may subsequently be realized in concrete risks in the form of the increasing occupational traumatism, occupational diseases, industrial accidents and catastrophes, which in turn will inevitably lead to a significant reduction of the labour potential of the country.

As is generally known, the errors made at the design stage, where, figuratively speaking, the vast majority of systems in this state are now, are practically impossible to correct at a later stage of operation when the system is already built and running. Therefore, it is relevant and important just in this transition phase that the potential risks are identified and effective measures and tools are developed in order to enable the building of the fundamental basis for the safe operation of technical systems in the period of the future economic growth of Ukraine.

The purpose of this article is aspecting the problems and perspective ways of the labour protection and industrial safety development in Ukraine at the stage of Association with EU.

To achieve this goal, it is necessary to solve the following tasks:

1. Comparative analysis of the structure of the industrial accident reasons in Ukraine and EU.

2. Problems of adapting the regulatory framework of Ukraine in the field of labour protection and industrial security to European standards.

3. Aspecting the systemic approach to training specialists in the field of labour protection and industrial safety in Ukraine and EU.

4. Priority ways of the labour protection and industrial safety development in Ukraine.

According to the Association Agreement with EU ratified by the Verkhovna Rada of Ukraine in 2014, Ukraine has undertaken obligations to introduce the provisions and requirements of the European Directives on the labour safety and hygiene in the national legislation. The said requirements are provided by Articles 419 to 425, Chapter 21, Section V "Economic and Sectoral Cooperation" of the Agreement, and specific requirements regarding the timing of implementation - in Annex XL in "Health and Labour Safety" [1].

Signing of the Agreement is certainly a positive step towards improving working conditions at the enterprises of this country, which in turn should have a positive effect on the positive dynamics of changes expressed in the decreased level of production traumatism and professional diseases. No wonder the authors emphasized the words "actual level" as it is an open secret today that Ukrainian enterprises quite often conceal the fact of occurrence of "minor" accidents that led to no worker death or injury.

However, the expected positive changes might only be possible and yield a significant result in combination with a different, progressive European approach to the labour protection management system, as well as corresponding changes in the minds of each employee.

Progressiveness of the European system of the labour protection management is based on a process of prediction, evaluation and further management of occupational risks for the purpose of their elimination or minimization. As to the domestic system, which is constructed and operates at most enterprises of the national economy, it has remained virtually unchanged since the Soviet times and is based on the process of analysis of accidents that have already occurred at the enterprise, which ends in the subsequent development of measures for the accidents prevention in the future. In other words, the European management system of professional safety and health is based on the methodology of risk prevention, while the domestic one - on the development of measures and means of safety in order to prevent the occurrence of further accidents, which have already de facto taken place. 
However, despite this fundamentally different approach to occupational risk management, statistics on causes of industrial accidents in Ukraine and EU countries practically correlate (Fig. 1).

So, in our country and EU countries the main causes of industrial accidents are organizational reasons mainly related to the non-performance (impossibility of performance), for some reason or other, of labour protection normative-legal acts. 50 to $70 \%$ of all accidents in
Ukraine and European countries [3 - 5] occur through organizational causes.

However, the situation will look significantly different (Figs 2 and 3) after analysing the data on the main injury indicators, such as fatal cases frequency coefficient $\left(\mathrm{k}_{\mathrm{ffc}}\right)$, the fatal accidents number and registered accidents total number ratio (the indicator recommended by ILO for countries with imperfect accidents accounting, which, unfortunately, include our state).

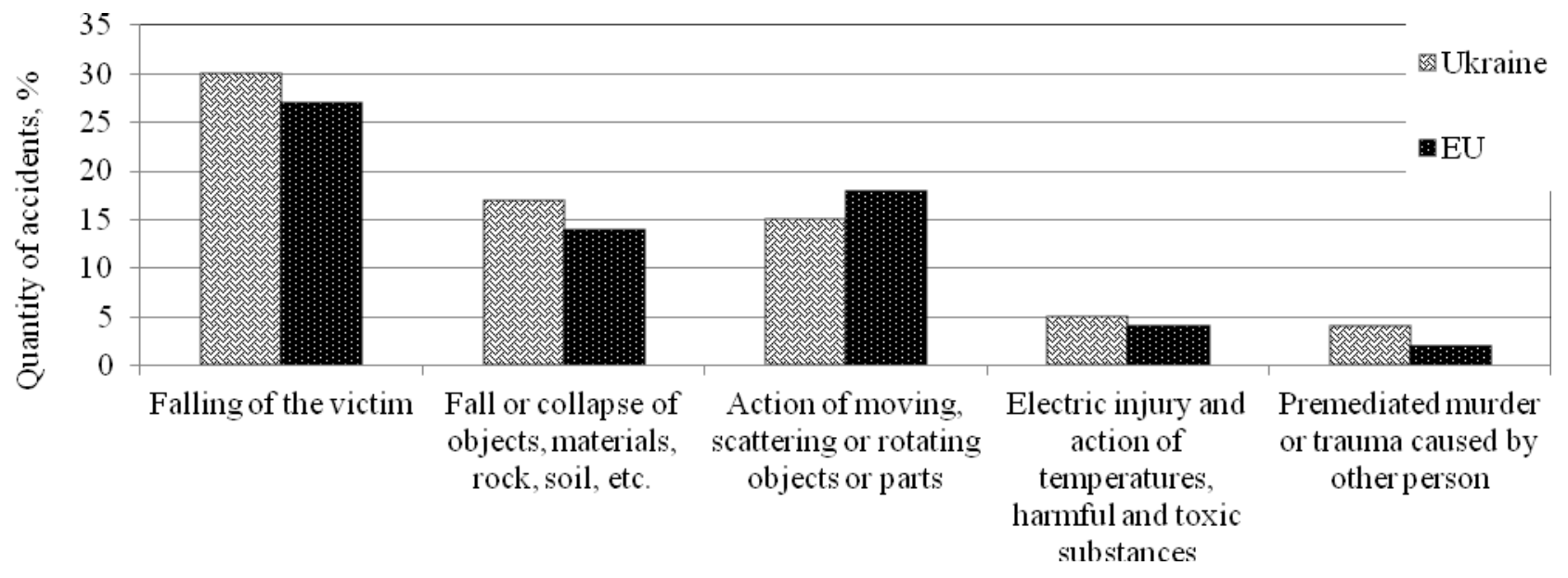

Fig. 1 - Distribution of industrial traumatism by the main types of events that caused accidents in Ukraine and EU countries [2]

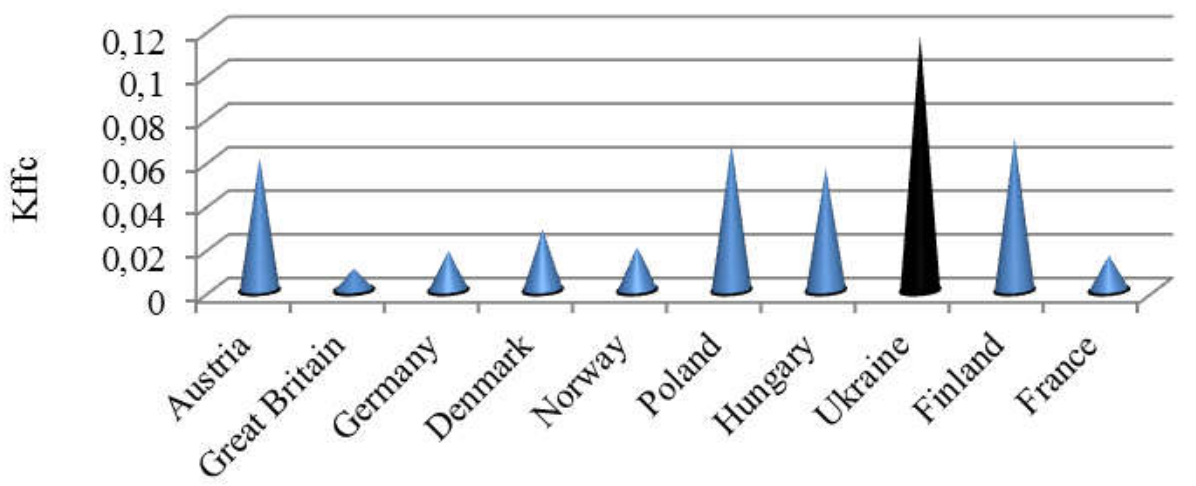

Fig. 2 - Fatal accidents frequency coefficient (per 1,000 of workers) in the EU countries and Ukraine [6, 7]

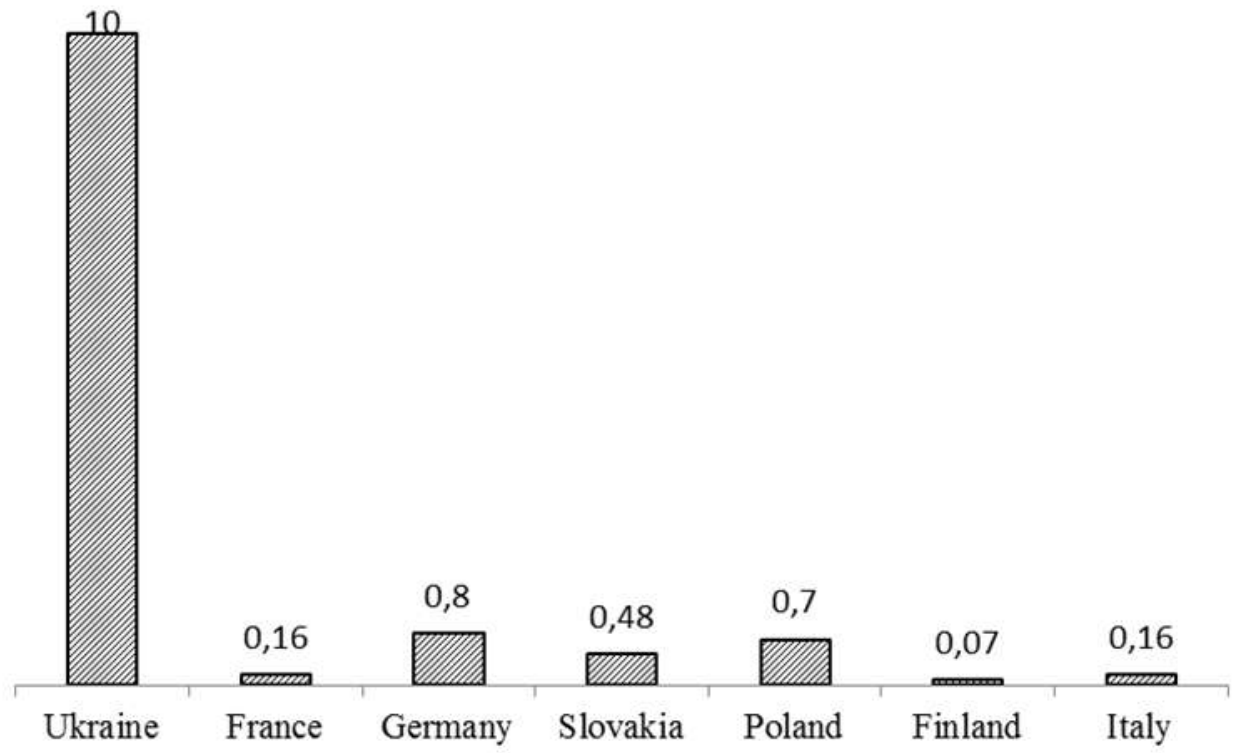

Fig. 3 - Fatal accidents number and registered accidents total number ratio in various countries [6, 7] 
Based on above data the question arises: why in spite of almost correlative data on accidents causes their severity is so much different, and is it safe to say that the implementation of the EU regulatory framework in the national legislation will lead to parity in the above figures? The answer to these questions should be considered in the context of two interrelated planes.

The first one concerns the systematics of fundamental changes in the labour protection legal framework of Ukraine, or rather the procedure of these changes implementation. The point is that the labour protection regulatory framework of Ukraine consists of more than 10,000 legal acts and is one of the largest and most extensive in the legal system of the state. All normative legal acts of Ukraine on labour protection are somehow interconnected, so to improve the situation in the field of labour protection and industrial safety an integrated approach is required, that is altering a single document should result in changing several others at the same time. This is a very difficult task, which is almost impossible to solve in a very short time. Possible errors of the legislation modification will inevitably affect the overall labour safety state and worsen it.

Here are just a few examples of already existing changes in the Ukrainian legislation.

Until recently, GOST 27331-87 "Fire Fighting Equipment. Classification of Fires" was applicable in Ukraine, however, from 1 January 2016, within the framework of the Agreement implementation it was replaced by the DSTU EN 2:2014 "Classification of Fires", which is actually a copy of the European standard EN 2:1992; EN 2:1992/A1:2004, IDT "Classification of Fires" translated into Ukrainian. The replacement was made under the Order issued by the Ministry of Economic Development and Trade of Ukraine №. 1494 dated 30.12.2014 "On Adoption of European and International Normative Documents as National Standards of Ukraine, Amendments to National Standards of Ukraine, Abolition of National Standards of Ukraine and Interstate Standards in Ukraine."

The new Ukrainian standard like the previous one distinguishes 5 classes of fires depending on the burning material: A, B, C, D, and adds a new class F that includes a fire associated with combustion substances, which are used for (in the process of) cooking (vegetable oils and animal oils and fats). That is the new standard does not provide, as the previous one did, the definition of a separate class of fire accompanied by the burning of energized electrical equipment (in accordance with GOST 27331-87 - class F), but introduces a new class, which is essentially duplicates classes $\mathrm{A}$ and $\mathrm{B}$, from the point of view of the firefighting equipment range. Giving effect to the new standard threatens with a dramatic increase in the number of injuries including fatalities that take place due to the occurrence and liquidation of fires involving the electrical installations combustion since according to statistics one of the main causes of fires in Ukraine is connected with short circuit and, accordingly, burning of electrical installation (Fig. 4.) [8, 9].

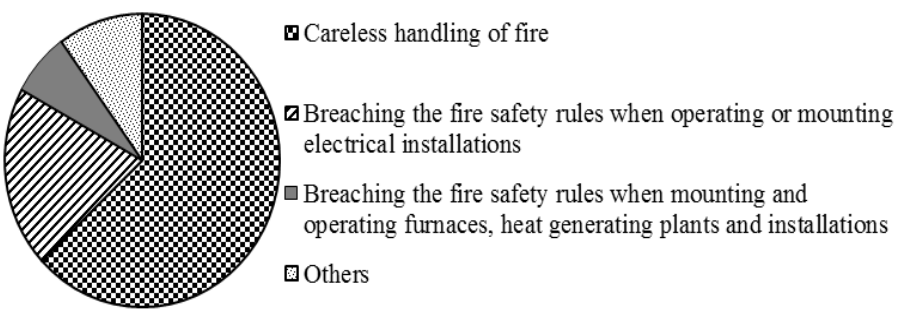

Fig. 4 - Origins of fire in Ukraine

This begs the question, what firefighting equipment is necessary to be used by both the worker and expert of The State Emergency Service of Ukraine (SES) during combustion of energised electrical installation, if such class of fires just does not exist? This issue has particular relevance in view of the fact that a certain number of potentially dangerous electrical installations is located in every industrial, social, or administrative premise.

In addition, the above mentioned changes had to entail the review of the other normative legal documents, primarily the Model Standards of fire extinguishers arrangement (NAPB B. 03.001-2004), which do not take into account the adopted fires classification amendments and do not contain any recommendations as to fitting the industrial, administrative and public buildings (premises, structures) characterized by the class $F$ fires with fire extinguishers.

The fire safety issue is given the first place in this article not without reason since the dynamics of the fires number and direct material losses caused by them are increasing in our country from year to year (Fig. 5) $[8,9]$.

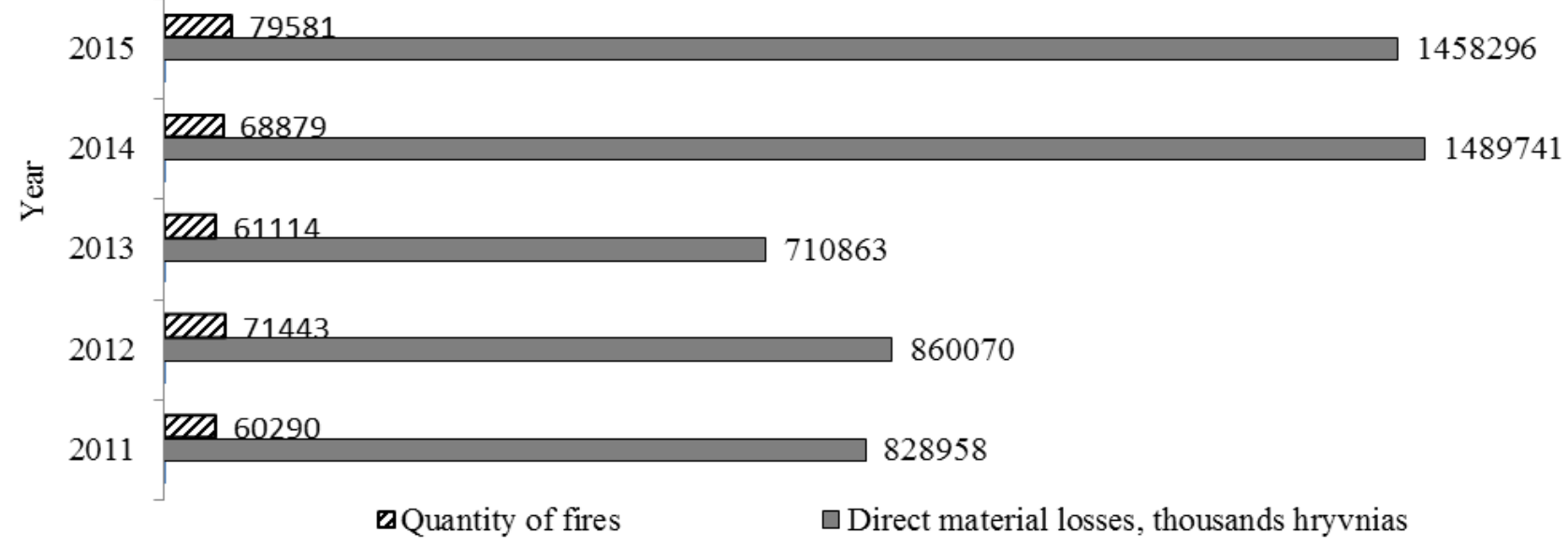

Fig. 5 - Dynamics of fires quantity in Ukraine and losses caused by their consequences 
However, despite this, the new Fire Safety Regulations in Ukraine include no requirements to fire and explosion security of such potentially dangerous objects as grain storages and dryers, which by their characteristics belong to the Category of B - "fire- and explosion-hazardous" (NAPB B.03.002-2007). Besides, the new Rules contain no fire safety requirements to engineering equipment of thermal networks, elevators, lifts and garbage chutes although the said technical systems are still designed, installed and operated in the territory of our country, and such examples are many.

It should be noted that the Fire Safety Rules in Ukraine is one of the basic regulatory documents on technical systems (TS) fire safety provision at the stage of design, installation and operation, and the lack of requirements for some of TS makes it impossible to achieve and maintain their safety.

From 1 August 2012, according to the Order of Ministry of Economic Development and Trade of Ukraine № 640 dated 28 May 2012 "On the Adoption of International and European Regulatory Documents as National Regulatory Documents by Confirmation," the European Standard IEC 62305-2010 IDT "Protection against Lightning", which received the name of DSTU EN 62305:2012 "Protection against Lightning" has taken effect in Ukraine. The Ukrainian version of the normative document, as well as European one, was approved and enacted in 4 parts, each of which has a separate number and title:

- DSTU EN 62305-1:2012, "Protection against Lightning. Part 1. General principles" (EN 62305-1:2011, IDT "Protection against Lightning - Part 1: General Principles");

- DSTU IEC 62305-2:2012 "Protection against Lightning. Part 2. "Risk Management" (IEC 623052:2010, IDT "Protection against Lightning - Part 2: "Risk Management");

- DSTU EN 62305-3:2012, "Protection against Lightning. Part 3. Physical Damage to Structures and Life Hazard" (EN 62305-3:2011, IDT "Protection against Lightning - Part 3: Physical Damage to Structures and Life Hazard"); and

- DSTU EN 62305-4:2012, "Protection against Lightning. Part 4. Electrical and Electronic Systems Located in Buildings and Structures" (EN 62305-4:2010, IDT "Protection against Lightning - Part 4: Electrical and Electronic Systems within Structures").

The standard DSTU EN 62305:2012 has been adopted in the English language and it has not been officially translation yet. Therefore, the designers that develop the system of protection from lightning are forced to rely on the accuracy of their own translation (or the same of a third-party translator), and thereby to interpret the requirements and make constructive decisions subjectively.

In addition, together with DSTU EN 62305:2012 the standard DSTU.B.V.2.5-38:2008 "Engineering Equipment of Buildings and Structures. Lightning Protection Devices of Buildings and Structures", which is actually the equivalent of IEC 62305-2006 "Protection against Lightning" and duplicates it, continues to operate in Ukraine. Such situation greatly increases the risk of making the wrong decisions at the stage of design and installation of lightning protection systems that may further, in the process of their operation, exert a negative effect at the level of production including fire security of the enterprise, and adversely affect the number of accidents, industrial accidents and catastrophes.

Along with the questions on the fire, explosion and electrical safety one of the most important problems of technical systems design are the sections that address the issues of industrial hygiene and occupational health, within whose framework the activities and means, which eliminate or minimize the impact of dangerous and harmful industrial factors on the workers are developed. The key sections among them are those relating to the achievement and maintenance of optimal parameters of microclimate in industrial premises, air purity, and illumination of the working area.

One of the basic documents, in accordance with which the sections addressing the creation of comfortable microclimate at work were being designed, was SNiP 2.04.05 - 91 "Heating, Ventilation and Air Conditioning". 1 January 2014 the said document was replaced by DBN V.2.5-56:2014 "Fire Protection Systems" and DBN V.2.5-67:2013 "Heating, Air Conditioning and Ventilation". However, appropriate links to SNiP that had lost its validity still remain included in the vast majority of sectoral and inter-sectoral normative regulatory acts on labour protection, which in its turn makes it impossible to design technical systems in compliance with the applicable sectoral NPAOPs.

As to the industrial illumination design the state of affairs here do not seem to improve in the future. The thing is that the annex on the daylight illumination calculation procedure has been excluded from the draft amendments to the existing DBN V.2.5-28:2006 "Engineering Equipment of Buildings and Structures". Natural and Artificial Illumination". The project proposes to rely on no natural illumination, but only to measure its coefficient (KPO), that is, to act after the accomplished fact. But then it is not clear how the design organizations should calculate the sizes of skylights for industrial, public and administrative buildings and rooms of different types and purposes with workplaces that require maintaining appropriate levels of natural illumination of the working area (indicators of KPO by the nature visual work).

Once again it should be emphasized that the examples presented above are not isolated cases of the existing problems in the labour protection legislative framework of Ukraine and indicate the continuation of negative trends of haphazard approach to its reformation, which was also stated by the authors in previous studies [5].

However, it is clear that the changes and quality of the legislative framework are only the foundation while the formation of different attitude to the individual and collective security and work culture in the mind of the worker is the prevalent factor in these occupational safety reforms implementation. That is, another most important plane, in the framework of which the issues of improving the state of occupational safety should be considered on the Ukraine's way to the European integration, is the formation in the person's conscience of the security and professional health priority as regards any 
production performance results. The development of such priorities, which are incidentally one of the main constitutional principles and state priorities of functioning of any country in the world, first of all takes place in the course of a future specialist gaining the appropriate level and quality of knowledge and competence when obtaining higher professional education. But despite the European way of reforming the educational system in Ukraine the level of domestic experts training in the field of labour protection and industrial safety qualitatively differs from the European one (is much worse than the latter), and in recent times has still deteriorated as compared to the previous curriculums.

A larger number of academic hours included in curriculum and programs, their branching in the relevant issues, emphasizing labour protection and industrial safety issues in the educational process, as well as a much larger number of educational institutions (in percentage) that are engaged in the training of labour protec- tion specialists can definitely be considered the advantages of the European educational system in comparison with the domestic one.

As an example we can consider the system of preparing the experts in the field of labour protection and industrial safety existing in our country and neighbouring Poland. Poland is used for the comparison due to its almost similar number of the economically active population (Ukraine - 20.1 million people, Poland - 17.01 million persons) and directions of the main economic activities (agriculture, machine building, metallurgy, coal and chemical industry, etc.) $[10,11]$. However, despite these correlative indicators the number of higher educational institutions, which train labour protection and industrial safety specialists as against the total number of higher educational institutions in Poland is almost 1.9-fold greater than in Ukraine (Fig. 6) with 1.18-fold less economically active population.

Poland

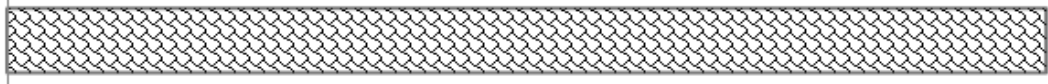

Ukraine

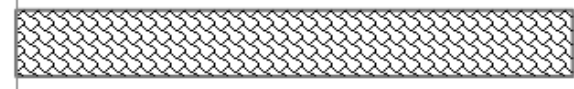

0

0,01

0,02

0,03

0,04

0,05

0,06

Fig. 6 - Ratio of the quantity of higher educational institutions that train labour protection and industrial safety specialists and their general number in Ukraine and Poland

Besides, the planned number of class hours for studying subjects related to labour protection and industrial safety at the higher educational establishment in Poland is 1.5 1.7 -fold greater than that in Ukraine. Work study programs at the higher educational institutions of our state include the study of two academic disciplines with a total number of 180 hours, they are "Life Activity Safety and Foundations of Labour Protection" and "Sectoral Labour Protection". In Polish higher educational institutions, the students are taught significantly more subjects related to labour protection and industrial safety when fulfilling curriculum. Among them there are "Safety and Ergonomics", "Physiology of Labour", "Human Factor in Systems of an Enterprise", "Labour Protection Management", "Organization of Labour Protection", "Risk Assessment and Analysis", "Analysis and Control of Contamination in Industrial Environment", etc. By the way, the situation similar to that at the Polish higher educational establishments is observed in other EU countries, where the labour safety issues are considered not only within the above mentioned subjects, but are necessarily integrated in a wide range of related subjects and curricula at all levels of training professionals starting from the elementary school.

But even in this shortened format as compared with European higher educational institutions of the subjects associated with labour protection, industrial safety and the safety during emergencies there have arisen recent certain negative tendencies to disallow the relevant departments to give consultations to students on the subject "Labour Protection and Safety in the Emergencies", withdraw these sections from the graduation projects, merge the appropriate subjects according to obscure criteria, significantly reduce the number of such subjects classroom teaching hours, replace exams with tests, and dismissively treat the labour protection, industrial safety and civil protection issues like minor ones in addition the infrastructure of the relevant departments has become obsolescent. These trends contradict both the current legislation of Ukraine in the field of occupational safety and common sense, and do not contribute to the maintenance of our graduates' high professional level in the labour protection and industrial safety.

According to Article 21, Law of Ukraine "On Labour Protection", the design of production facilities, development or modification of technologies (both of technical and intellectual nature), means of production, etc. (that is all the actions that a student performs as part of the writing of Diploma) must fully comply with the requirements of labour protection normative legal acts [12]. The above mentioned article also provides for the project documentation compulsory inspection for conformity with its requirements. Given the fact that the labour protection regulatory framework of Ukraine includes over 10,000 documents, verification of such conformity and examination can only be carried out by highly qualified professionals (at the higher educational institutions these are the faculty of Life Activity Safety or Labour Protection chairs). As diploma thesis is essentially the qualification characteristics of the graduate as a future top manager of the enterprise who, in accordance with Article 13 of Law of Ukraine "On Labour Protec- 
tion" shall bear direct responsibility (from administrative to criminal one, Article 44 of the Law [12]) for the security, life and health of every member of the labour collective, his/her expertise in the field in question is a priority. Qualification of the teachers of the respective chairs in the field of labour protection and industrial safety shall be confirmed and constantly improved resulting in the availability and development of specialised scientific and scientific-methodical works, practical experience and certificates of training for the right of teaching the relevant subjects and providing consultations on the diploma project section "Labour Protection and Safety in Emergency Situations". Such course of training in accordance with the "Model Provisions on Training and Testing of Knowledge on Labour Safety" (NPAOP 0.00-4.12-05) can and shall only be completed by lecturers of Life Activity Safety or Labour Protection Chairs. In other words, giving consultations on Section "Labour Protection and Safety in Emergency Situations" by the faculty of the chairs that teach professionals is contrary to the requirements of the current Model Provision. And the exception of Sections "Labour Protection and Safety in Emergency Situations" from the students' diploma projects and lack of qualified expert verification for compliance with the applicable requirements of the legislation question the legitimacy of the graduation project and as a result the higher education diplomas received.

Another source of concern is the initiative to merge in the curricula and work programs such diverse as to their purpose and essence subjects as, for example, "Sectoral Labour Protection" and "Civil Protection", which require different levels of knowledge and competence from the students. Such a merger is not only contrary to Clause 2.1 of the Model Provision, but also makes the quality mastering of the material impossible for the students due to the absence of elementary logical connections between these subjects.

In addition to this surprising practice that includes various forms of the term knowledge control on the said subjects for students of different groups who attends lectures in a single stream.

In this way the lines of reforming the higher and professional education in Ukraine should be determined by the priority and exclusivity of the issues of labour protection and industrial safety in the curricula for training specialists in accordance with the general European concept, which may conventionally be represented as a continuous process of learning and improving knowledge in the matters of ensuring the occupational safety and health during the whole period of each person labour activity [13].

A negative tendency of unsystematic approach to reforming the labour protection legislative framework of Ukraine, reduced quality of the relevant regulatory documents, as well as disregard of the labour protection and industrial safety both in the educational process of training professionals and at the national and household levels, has already been expressed in the negative dynamics in the number of accidents in our country, and all this taking place despite the industrial production significant contraction in traditionally most dangerous industries: mining, chemical, metallurgical, etc. Thus, only during the first half of 2016, the number of accidents increased by $3.4 \%$ as compared to the same period in 2015, while the number of fatal injuries in some regions of Ukraine saw a several-fold increased (Volyn Region 3.7, Cherkasy Region -7 and in Kyiv Region - 1.7). The main causes of accidents were traditionally organisational ones: non-compliance with the requirements of labour protection instructions $(36.4 \%$ of the total accidents) and through the personal negligence of the victim (14.8\% respectively) [14].

In consideration of a certain delayed in time negative effect from the measures taken during recent years in the course of law and education reforms as regards labour protection that affect the security production, we can make a cautious forecast of an increase in the values of the above indicators in near future.

So, in what directions should we take the immediate strategic steps that can radically and in due time give positive results?

First, it is necessary to develop and implement in the form of special software the concept of a unified state automated register of normative legal documents on labour protection. Such software must allow the developers and legislators to amend the existing legal documents in the course of replacing the obsolete documents or developing new NPAOPs in a timely manner, efficiently and in full. The implementation of the above mentioned software will put an end to the haphazard approach to reforming the legal framework on labour protection and will significantly enhance the safety of technical systems at all life cycle stages from design to operation, and considerably decrease (by increasing the quality of the composition of NPAOPs) the number of cases of occupational traumatism, occupational diseases and industrial accidents and disasters that are caused by the organizational and technical reasons.

The second line, which is also the way to significantly affect the reduction of accidents due to organisational reasons, is to improve the quality of education in the field of labour protection and industrial safety together with the simultaneous promotion of these issues at the national and household levels, in the educational process and in production environment. However, the proposed measures maximum efficiency may only be attained when they are lobbied for first of all at the state level in the form of efficient functioning of the existing labour protection and industrial safety legislative acts and elaboration of the new ones starting with amendments to curricula (adding core subjects, increasing the number of classroom hours, providing for mandatory inclusion of the relevant sections in the graduation projects of the students of all specialties, examining these projects by experts in labour protection, etc.) ad modum the European higher educational establishment.

The outcomes of this article enable the following conclusions:

1. The main reasons of industrial accidents both in Ukraine and EU are organizational ones whose share in the accidents total amount makes 50 to $70 \%$. However, the value of the fatal cases frequency coefficient (per 1 thousand employees), and the ratio of fatal accidents and the total number of registered accidents in EU is on the average 2-fold and 100-fold lower than in Ukraine, respectively. 
2. The solution to the problem of improving the state of industrial safety in Ukraine on the way of European integration should be considered in the context of two major interrelated planes: reformation of the legal and educational systems.

3. One of the main problems of adapting the national legislation to the European one, as far as the sphere of labour protection and industrial safety is concerned, is the unsystematic approach and lack of a comprehensive one to changes in the relevant normative legal framework of Ukraine, which in turn leads not only to its inefficiency, but also provokes new potential dangers.

4. The level of training of domestic experts in the field of labour protection and industrial safety differs

\section{REFERENCES}

1. The Association Agreement between the European Union, Euratom, their 28 Member States and Ukraine // Electronic access: http://zakon5.rada.gov.ua/laws/show/984_011/page

2. The Analysis of Causes of Accidents Professional Diseases Occurrence in EU Countries // Electronic access: http://ec.europa.eu/eurostat/web/main/home

3. A. P. Bochkovsky "Human Factor" and Professional Risk: Fortuity or Law // Grain Products and Combined Feeds, 2014, 4(56). - P. 7-13.

4. A. P. Bochkovsky Priority Lines of Improving Labour Protection Management System at the Enterprises // Grain Products and Combined Feeds, 2014, 2(54). - P. 11-16.

5. A. P. Bochkovsky Promising Direction for Improving Regulatory Legal Framework on Labour Protection for Enterprises Producing Food and Beverages / A. P. Bochkovsky, N. Yu. Sapozhnikova // Environmental Safety Balanced Use of Resources (Section of Environmental Engineering and Life Activity Safety), 2015, No. 2 (12). - P. 85-93

6. A. P. Bochkovsky Theoretics of Efficiency Potential Criterion Score of the Labour Protection Management System // Bulletin of the Lviv State University of Life Safety, 2015, No. 12. - P. 100-107

7. Current State of Labour Protection in Ukraine. Trade-Union Information and Analytical Report. - Kyiv, 2015 - P. 12 // Electronic access: http://www.fpsu.org.ua

8. World Fire Statistics. Report Nos 20 - 16 / The International Association of Fire-Fighting Services. The Fire Statistics Centre // Electronic access: www.ctif.org

9. Information and Analytical Note of Emergency Situation in Ukraine 2011-2015 / The State Emergency Service of Ukraine // Electronic access: http://www.dsns.gov.ua/

10. Economy of Ukraine // Electronic access: https://ru.wikipedia.org/wiki/,

11. Economy of Poland // Electronic access: https://ru.wikipedia.org/wiki/

12. Law of Ukraine "On Labour Protection" // Electronic access: http://zakon2.rada.gov.ua/

13. European Agency for Safety and Health at Work // Electronic access // https://osha.europa.eu/

14. The Analysis of Ensured Industrial Accidents and Professional Diseases, $1^{\text {st }}$ halves of 2015 and $2016 /$ The Fund of Social Insurance against Industrial Accidents and Professional Diseases of Ukraine. Current information // Electronic access: http://www.social.org.ua/activity/stat

А.П. БОЧКОВСЬКИЙ ${ }^{1}$, канд.техн.наук, доцент, Н.Ю. САПОЖНІКОВА ${ }^{2}$ канд.техн.наук, старш. викл., В.Д. ГОГУНСЬКИЙ ${ }^{1}$, д-р техн. наук., професор

${ }^{1}$ Одеський національний політехнічний університет, м. Одеса

${ }^{2}$ Одеська національна академія харчових технологій, м. Одеса

\section{ОХОРОНА ПРАЦІ ТА ПРОМИСЛОВА БЕЗПЕКА В УКРАЇНІ: ПРОБЛЕМИ ПЕРЕХІДНОГО ПЕРІОДУ ТА ПЕРСПЕКТИВНІ ШЛЯХИ РОЗВИТКУ}

\section{Анотація}

В статті, на основі порівняльного аналізу причин виникнення нещасних випадків на виробництві 8 Україні та краӥнах ЄС, встановлено, щзо основними з них є організаційні (50 до 70 \% від загальної кількості випадків), однак такі показники як коефіцієнт частоти смертельних випадків (із розрахунку на 1 тис. працівників) та співвідношення кількості нещасних випадків зі смертельним наслідком до загального числа зареєстрованих нещасних випадків в Україні перебільшують аналогічні показники в країнах Європи приблизно у 2 та 100 разів відповідно.

Зазначено, щчо питання поліпшення стану безпеки праиі в Украӥні на шляху асоиіаиії з Свропейським Союзом, слід розглядати в розрізі двох основних площчи, щэо пов'язані зі змінами у законодавчій та освітній системах.

В рамках статті авторами проаналізовані основні міжсалузеві та галузеві нормативно-правові акти з охорони праці, зокрема, у галузі забезпечення пожежовибухо- та електробезпеки, а також відповідні документи, щуо стосуються створення та забезпечення комфортних умов праці на робочому місті. 
На основі проведеного аналізу, визначені проблеми адаптації вітчизняного законодавства в галузі охорони прачі та промислової безпеки до законодавчої бази $С С$, які стосуються безсистемності і вибірковості підходу до впровадження відповідних змін, а також потенційні небезпеки, що можуть виникнути на всіх стадіях життєвого циклу технічних систем у разі їх запровадження.

Проаспектовані основні відмінності у системному підході до фахової підготовки студентів у вищих навчальних закладах України та країн Євросоюзу (на прикладі Польщі) в галузі охорони праці та промислової безпеки. Зазначено, щзо у республічі Польща при співвідносною з Україною загальною кількістю населення, кількість спеціальних вищих навчальних закладів, щуо готують спеціалістів в галузі охорони праці, по відношенню до загальної кількості вишів, перевищує відповідний показник в Україні в 1,9 рази, а кількість навчальних дисииплін, щзо стосується питань охорони праці та промислової безпеки та читаються студентам в рамках виконання робочих програм у непрофільних ВНЗ Польщі в рази більша за украӥнські.

Наведені та проаналізовані статистичні дані, щзодо динаміки збільшення та причин нещасних випадків в Україні за відповідні періоди 2015 та 2016 років в розрізі останніх негативних змін щзодо скорочення навчальних часів на вивчення студентами дисииллін «Охорона праці в галузі», "Основи охорони праці», «Безпека життєдіяльності» та «Цивільний захист», їх злиття, а також відміни у більшості вимів України відповідних розділів дипломних проектів.

На основі проведених досліджень, запропоновані пріоритетні напрями розвитку охорони праці та промислової безпеки в Украӥні на етапі євроінтеграції.

Ключові слова: охорона прачі, промислова безпека, нормативно-правова база, асочіація з СС, законодавство, освіта, небезпека, технічна система.

\section{ЛITЕРАТУРА}

1. Угода про асочіачію між Украӥною, з однієї сторони, та Свропейським Союзом, Свропейським співтовариством з атомної енергї $і$ їхніми державами-членами, з іниої сторони // Електронний режим достуny: http://zakon5.rada.gov.ua/laws/show/984_011/page

2. Аналіз причин настання нещзасних випадків та професійних захворювань в краӥнах ЄС // Електронний ресурс доcmyny: http://ec.europa.eu/eurostat/web/main/home

3. Бочковський А.П. «Людський фактор» та професійний ризик: випадковість чи закономірність // Зернові продукти і комбікорми, 2014, 4(56). - С. 7-13.

4. Бочковський А.П. Пріоритетні напрямки удосконалення системи управління охороною праці на підприємствах // Зернові продукти і комбікорми, 2014, 2(54). - C. 11-16.

5. Bochkovskyi A. P. Promising direction for improving regulatory legal framework on labour protection for enterprises production food and beverages / Bochkovskyi A. P., Sapozhnikova N. Yи // Екологічна безпека та збалансоване ресурсокористування (секція Інженерія середовища та безпека життєдіяльності), 2015, № 2 (12). - С. 85-93

6. Бочковський А.П. Теоретичні аспекти критеріальної оцінки потенціалу ефективності системи управління охороною праці // Вісник Львівського державного університету безпеки життедіяльності, 2015, № 12. - С.100-107

7. Сучасний стан охорони прачі в Україні. Інформачійно-аналітична профспілкова доповідь. - Київ, 2015 p. - C. 12 // Електронний режим доступу: http://www.fpsu.org.ua

8. Світова пожежна статистика. Звіт № 20 - 16 / Міжнародна асоціація Пожежно-рятувальних служб. Центр пожежної статистики // Електронний режим доступу: www.ctif.org

9. Інформачійно-аналітична довідка про надзвичайні ситуачії в Україні, щуо сталися впродовж 2011 - 2015 рр. / Державна служба Украӥни з надзвичайних ситуачій // Електронний режим доступу http://www.dsns.gov.ual

10. Економіка Украӥни // Електронний режим доступу: https://ru.wikipedia.org/wiki/,

11. Економіка Польщі // Електронний режим достуnу: https://ru.wikipedia.org/wiki/

12. Закон Украӥни «Про охорону прачі» // Електронний режим доступу: http://zakon2.rada.gov.ua/

13. Свропейська агенція з безпеки та гігієни праці на робочому місиі // Електронний режим доступу// https:/losha.europa.eu/

14. Аналіз страхових нещзасних випадків на виробнищтві та профзахворювань за I півріччя 2015 р., 2016 р. / Фонд сочіального страхування від нещзасних випадків на виробництві та професійних захворювань України. Оперативна інформація // Електронний ресурс доступу: http://www.social.org.ua/activity/stat 